\title{
Correction to: Prevalence and factors associated with PTSD among female urban slum dwellers in Ibadan, Nigeria: a cross- sectional study
}

\author{
Olutoyin Sekoni ${ }^{1,2^{*}}$, Sumaya Mall ${ }^{2+}$ and Nicola Christofides ${ }^{2+}$
}

\section{Correction to: BMC Public Health 21, 1546 (2021) http://orcid.org/10.1186/s12889-021-11508-y}

It was highlighted that in the original article [1] the Funding section was incorrect. This Correction article shows the correct Funding section. The original article has been updated.

\section{Funding}

OS was supported by the Consortium for Advanced Research Training in Africa (CARTA). CARTA is jointly led by the African Population and Health Research Center and the University of the Witwatersrand and funded by the Carnegie Corporation of New York (Grant NoG-19-57145), Sida (Grant No:54100113), Uppsala Monitoring Centre and the DELTAS Africa Initiative (Grant No: $107768 / Z / 15 / Z)$. The DELTAS Africa Initiative is an independent funding scheme of the African Academy of Sciences (AAS)'s Alliance for Accelerating Excellence in Science in Africa (AESA) and supported by the New Partnership for Africa's Development Planning and Coordinating Agency (NEPAD Agency) with funding from the Wellcome Trust (UK) and the UK government. The statements made and views expressed are solely the responsibility of the Fellow.
SM has been supported by a Claude Leon award for early career researchers and a self-initiated research fellowship from the South African Medical Research Council (2018-2020).

The funders had no role in the design of the study, collection, analysis, and interpretation of data nor in writing the manuscript.

Published online: 27 September 2021

\section{Reference}

1. Sekoni, et al. Prevalence and factors associated with PTSD among female urban slum dwellers in Ibadan, Nigeria: a cross-sectional study. BMC Public Health. 2021;21:1546. https://doi.org/10.1186/s12889-021-11508-y.

*Correspondence: t1 toyin@yahoo.com; oosekoni@com.ui.edu.ng

'Sumaya Mall and Nicola Christofides contributed equally to this work. 'Department of Community Medicine, College of Medicine, University of Ibadan, Queen Elizabeth Road, Ibadan, Nigeria

${ }^{2}$ School of Public Health, University of the Witwatersrand, 27 St Andrews

Road, Parktown 2193, South Africa

C C The Author(s). 2021 Open Access This article is licensed under a Creative Commons Attribution 4.0 International License, which permits use, sharing, adaptation, distribution and reproduction in any medium or format, as long as you give appropriate credit to the original author(s) and the source, provide a link to the Creative Commons licence, and indicate if changes were made. The images or other third party material in this article are included in the article's Creative Commons licence, unless indicated otherwise in a credit line to the material. If material is not included in the article's Creative Commons licence and your intended use is not permitted by statutory regulation or exceeds the permitted use, you will need to obtain permission directly from the copyright holder. To view a copy of this licence, visit http://creativecommons.org/licenses/by/4.0/. The Creative Commons Public Domain Dedication waiver (http://creativecommons.org/publicdomain/zero/1.0/) applies to the data made available in this article, unless otherwise stated in a credit line to the data. 